\title{
Por uma linguagem andrógina
}

Patricia Marouvo

Doutoranda em Letras pela Universidade Federal do Rio de Janeiro, patriciamarouvo@yahoo.com.br.

Manuel Antônio de Castro Professor emérito da Universidade Federal do Rio de Janeiro, profmanuel@gmail.com.

\section{Resenha do livro:}

PINHO, Davi. Imagens do feminino na obra e na vida de Virginia Woolf. Curitiba: Appris, 2015.

Recebido em 31 de março de 2016 Aceito em 14 de junho de 2016

Num mundo onde a falta de comunicação parece sugerir uma insdisponibilidade para a escuta atenta do que se insinua nas entrelinhas da fala do outro e da nossa, pensar a possibilidade de sensibilização para o silêncio do que se diz e se ouve torna-se fundamental. Ainda no século XXI, a literatura de Virginia Woolf suscita questionamentos de suma importância para uma reflexão acerca do projeto humanista que se pretende construir, atentando primordialmente para os grandes pilares sobre os quais a cultura europeia foi edificada: uma linguagem masculina e uma linguagem outra, feminina. Essas duas linguagens, concomitante e especularmente construídas, afirmam ainda hoje uma bipolaridade de mentalidades que sustentam as estruturas da sociedade patriarcal, cujos construtos vêm sendo largamente reavaliados, mas ainda vagarosamente desconstruídos nos últimos dois séculos.

Um exercício crítico da obra e da vida da escritora e ensaísta é desenvolvido no livro de Davi Pinho intitulado Imagens do feminino na obra e vida de Virginia Woolf. A partir de diversos escritos, dentre eles romances, ensaios, diários, entrevistas e as memórias da autora, aos poucos uma imagem do texto woolfiano é delineada, atando as duas pontas da vida da artista, o mundo em que habita com suas personagens e o 
mundo em que socializa com seus companheiros do grupo de Bloomsbury, formado por intelectuais e artistas modernistas, como Lytton Strachey, Leonard Woolf, Saxon Sydney-Turner, Roger Fry, Desdmond MacCarthy, E.M. Forster, John Maynard Keynes, Thoby Stephen e Vanessa Bell.

Dividido em duas partes, o livro procura primeiramente, em "A passagem de Kensington para Bloomsbury", refletir sobre a trajetória das irmãs Virginia Woolf e Vanessa Bell e sua contribuição para a sensibilização da mente masculina de Cambridge. Dialogando com o livro The Phantom Table (2000) de Ann Banfield, Davi Pinho afirma que, como a vida acadêmica, cujo acesso era permitido somente aos homens, propagava conceitos universais e verdades últimas que confirmassem a racionalização de sujeitos mediante a objetificação dos fenônemos, a origem de Bloomsbury não encontra-se nas influências que as palestras de Bertrand Russell e de G.E. Moore tiveram sobre os Cambridge Apostles, os apóstolos de Cambridge. Se por um lado, alguns membros do grupo tiveram acesso a esse discurso masculino, por outro a prática filosófica e artística dos integrantes sinaliza uma necessidade de redimensionamento do que se compreende por realidade, sendo esta reconfigurada a partir do que diferentes perspectivas possibilitam entrever. "Os Bloomsberries descobrem uma maneira de olhar sem nomear, sem dar um sentido prévio que reafirme a subjetividade de quem vê, e cristalize as antigas associações - uma verdadeira revaloração da antiga relação entre significado e significante" (p. 51).

Davi Pinho argumenta que essa revaloração é ensejada pelo olhar feminino, que, historicamente confinado ao silêncio opressor da força masculina do patriarcado inglês, foi limitado aos confins da casa. Ali, a mulher deveria atuar como o Anjo do Lar, símbolo da imaculação e preservação das instituições vitorianas, ou como os Demônios do Lar, encarnados nas "bruxas, as pacientes da cura pelo descanso, as prisioneiras nos sótãos" (p. 165), dentre outras párias da sociedade por desequilibrarem o centro de forças de uma nação imperialista, gerida por homens, verdadeiros sujeitos, cujo reflexo elas não poderiam aumentar numa posição objetal.

O olhar feminino, ocupando este lugar de alteridade, admite outras posições e outras perspectivas acerca da realidade que as não oficiais, e exatamente por entender-se 
como o outro, reconhece a alteridade dos outros, podendo questionar o lugar central ocupado pelo masculino. Virginia Woolf e Vanessa Bell, por não terem tido acesso à rigorosidade do ambiente acadêmico de Cambridge, como seus irmãos tiveram, estavam, assim, disponíveis à percepção de relações outras com as pessoas e com o não-saber que não a de competitividade, estimulada pelos discursos patriarcais como o acadêmico, o militar, o político e o religioso. Ressaltase, portanto, que as mulheres de Bloomsbury tiveram papel decisivo na consolidação de uma percepção poética do que é e do como se conhece a realidade, seja na ficção de Virginia a partir das personagens Lily Briscoe de To the Lighthouse (1927) e Mrs. Dalloway no romance homônimo (1925), ou na pintura "Studland Beach" (1912) de Vanessa.

Na segunda parte do livro, "Between the Devil and the Deep Sea': écriture feminine e o acesso à androginia", caminhos são propostos para a instauração de novos modos de compreensão da literatura woolfiana em diálogo com o livro Que é a literatura? (1948) de Jean-Paul Sartre e a écriture feminine das feministas da década de 70, atentando-se aos limites tanto da linguagem masculina quanto da linguagem feminina. Se num primeiro momento, a dicotomia sartriana entre a poesia, silenciosa, e a prosa, engajadora, vai de encontro ao que Virginia Woolf se propõe com sua prosa poética, podemos perceber posteriormente que o engajamento existencialista parte do pressuposto de que algo definido e acabado, um produto comunicável, é fabricado por romancistas. No entanto, Davi Pinho aponta muito claramente para a dificuldade de interpretação da ficção woolfiana como uma tentativa didática de mover leitores a uma determinada maneira de posicionar-se no mundo, movimento típico da linguagem masculina. Buscando o silêncio da poesia, característico da linguagem feminina, a prosa poética da escritora insinua por "palavras quebradas", termo utilizado pelas personagens Bernard em The Waves (1931) e Hewet em The Voyage Out (1915), a intangibilidade do it da vida sobre o qual não se deseja palestrar, mas sim pincelar em uma imagem tão viva que seja auto-suficiente para sobreviver à pequena vida útil de uma simples mensagem.

Sartre, em seu recorte metafísico, não alcança a unidade da linguagem que Virginia chama de andrógina. 
No último capítulo de seu livro, Davi Pinho aproxima as questões abordadas por Hélène Cixous na década de 70 da androginia proposta por Woolf na década de 30. "A mente andrógina é a possibilidade de uma mente que esteja para além da afirmação do mesmo, e negação do outro, e, nesse sentido, ela é uma afirmação, ou efetivação, da diferença" (p. 189). O grito assertivo de uma linguagem masculina que quer subjugar é apaziguado pela sensibilidade feminina que, antes de mais nada, procura ouvir a alteridade anunciada pelo outro. Na unidade entre diferentes, a propriedade do ser humano livre brilha nos interstícios de compreensão e produção dessas duas linguagens historicamente construídas. O feminino em Virginia Woolf "pode ser considerado uma quebra ontológica" (p. 185), um primeiro passo que encaminhe artistas e pensadores rumo à linguagem. Uma linguagem sem adjetivações. Puramente andrógina.

Olivro de Davi Pinho destaca-se por ressaltar a pertinência e a atualidade da produção do grupo do Bloomsbury mas, principalmente, da poética woolfiana, fazendo interagir as diferentes vozes que habitam o universo da escritora. Além disso, é importante salientar a erudição de um texto que minuciosamente dialoga com outros diversos integrantes do cânone das literaturas de língua inglesa, permitindo a seus leitores uma contextualização, principalmente do pensamento vitoriano e do pensamento modernista. Mas é, sobretudo, pela desenvoltura no tratamento das imagens poéticas que o texto torna-se encantador e inebriante. O cuidado com o sentido global que cada imagem estabelece, tanto com as obras literárias quanto com os ensaios, revela a precisão e o rigor na elaboração de um livro em que as parte relacionam-se com o todo na poética woolfiana. 